\title{
Presence and enzymatic activity of prostate-specific antigen in archival prostate cancer samples
}

\author{
SNEZANA VUKMIROVIC-POPOVIC ${ }^{1}$, NICHOLAS G. ESCOTT ${ }^{2}$ and \\ WILHELMINA C.M. DUIVENVOORDEN ${ }^{1,3,4}$
}

\begin{abstract}
${ }^{1}$ Department of Pathology and Molecular Medicine, McMaster University, 1280 Main Street West, Hamilton, Ontario L8N 3Z5; ${ }^{2}$ Department of Pathology, Thunder Bay Regional Health Sciences Centre, 980 Oliver Road, Thunder Bay, Ontario P7B 6V4; ${ }^{3}$ Juravinski Cancer Centre, 699 Concession Street, Hamilton, Ontario L8V 5C2; ${ }^{4}$ Department of Chemistry and Biology, Lakehead University, 955 Oliver Road, Thunder Bay, Ontario P7B 5E1, Canada
\end{abstract}

Received February 25, 2008; Accepted June 3, 2008

DOI: $10.3892 /$ or_00000089

\begin{abstract}
Patients with advanced prostate cancer frequently have a poor prognosis as a result of metastasis. The serum prostate-specific antigen (PSA) test is widely used for the diagnosis of prostate cancer. The enzymatic activity of PSA may be involved in the invasion of prostate cancer. We set out to determine the prevalent form of PSA in human prostate adenocarcinoma samples by ELISA and Western blot analysis and its enzymatic activity using a synthetic substrate S-2586 and fibronectin. Our results show that in serum from prostate cancer patients and in tumour homogenates, the prevalent form was PSA bound to $\alpha 1$-antichymotrypsin. All homogenates showed enzymatic activity towards a synthetic PSA substrate, whereas only five samples showed activity at $28 \mathrm{kDa}$ towards fibronectin as determined by enzymography, which is most likely due to active PSA. Human prostate cancer LNCaP cells produced largely inactive PSA. In comparison, 22Rv1 cells produced 29-fold less PSA, but with high specific activity. Similarly, our results from the human prostate cancer tissue samples also show that free PSA appears to exist in diverse forms of very different specific activity. Since PSA, as a serine protease, may be involved in the invasion of prostate cancer, our results suggest that prostate cancers have potentially diverse invasive capacity due to differences in specific enzymatic activity of PSA.
\end{abstract}

Correspondence to: Dr Wilhelmina Duivenvoorden, Juravinski Cancer Centre, Research Department Room 4-227, 699 Concession Street, Hamilton, Ontario L8V 5C2, Canada

E-mail: helga.duivenvoorden@jcc.hhsc.ca

Abbreviations: ACT, $\alpha 1$-antichymotrypsin; CM, conditioned medium; PSA, prostate-specific antigen; TPCK, tosyl phenylalanyl chloromethyl ketone

Key words: prostate-specific antigen, enzyme activity, prostate cancer, serum

\section{Introduction}

Patients with advanced prostate cancer frequently have a poor prognosis as a result of metastasis. The 5-year survival rate for men diagnosed with advanced prostate cancer is only $33.5 \%$, compared to $100 \%$ when the cancer is initially diagnosed as localised (1). There are several lines of evidence suggesting that the serine protease, prostate-specific antigen (PSA), could be involved in cancer cell invasion and metastasis. PSA is generally known as a diagnostic marker for prostate cancer and is also used for monitoring of the disease. Physiologically PSA hydrolyzes semenogelins I and II to increase sperm motility (2). Other substrates of PSA include fibronectin (3) and insulin-like growth factor binding proteins (4). The cleavage of these substrates by PSA may be related to its involvement in cancer cell invasion $(5,6)$.

Increased serum PSA levels correlate to tumour volume (7) and most probably result from leakage of PSA from the prostatic ductal system into the prostatic stroma and subsequently into the blood stream. The serum PSA test measures total PSA, which has been defined to consist of all immunodetectable PSA and comprises mostly of free PSA and PSA bound to the protein inhibitor $\alpha 1$-antichymotrypsin (ACT) (8). One of the various forms of free PSA, pro-PSA, the latent form of PSA, has to be activated by the action of specific other proteases, likely kallikrein-2, -4 or -15 (9).

As opposed to serum, where PSA correlates to tumour volume, PSA staining intensity in tumour tissue has been shown to inversely correlate to the Gleason score. By immunohistochemistry $(7,10)$ and similarly by in situ hybridization (11), prostate cancer tissue shows less staining for PSA than benign prostatic hyperplasia. In tissue homogenates, PSA correlates inversely with tumour stage and cytological grade and is a much better indicator of prostate cancer than serum PSA $(12,13)$.

We set out to determine the prevalent form of PSA and its activity in human prostate tumour samples towards several substrates and compare the results to serum from prostate cancer patients and human prostate cancer cells. The enzymatic activity of PSA in prostate cancer tissue has not been studied, with the exception of a study by Denmeade et al (14) in which 
explant tissue from human prostate tumour samples was used to determine that $>80 \%$ of PSA is active. The activity was measured using a fluorescent synthetic oligopeptide, which may not be biologically relevant, as PSA cleaves its physiological substrates, semenogelins I and II and fibronectin, at many different sites and amino acids (15).

\section{Materials and methods}

Patient population and sample collection. The research project was approved by the Thunder Bay Regional Health Sciences Centre Research Ethics Team and the Board Ethics Committee of St. Joseph's Care Group (Thunder Bay, ON, Canada). Signed informed consents were obtained from patients before the processing of the samples. Serum of six prostate cancer patients with PSA $>100 \mathrm{ng} / \mathrm{ml}$ was available. Patients had histologically documented prostate adenocarcinoma and ranged from 43 to 83 (median 73) years of age. Venous blood samples were collected in $10 \mathrm{ml}$ tubes and allowed to clot. The serum was frozen at $-80^{\circ} \mathrm{C}$ until performance of the analysis. Human prostate adenocarcinoma samples were obtained after prostatectomy between 1992 and 1995. The Gleason scores for each of the samples were obtained from records in the Pathology Department and were blindly assessed by S. V.-P. using midway sections from the frozen samples $(16,17)$. Samples were snap-frozen in liquid nitrogen and kept at $-80^{\circ} \mathrm{C}$. Up to ten $8-\mu \mathrm{m}$ thick sections of frozen tumour samples were homogenised in $1 \%$ SDS using a Potter-Elvehjem tissue grinder. The amount of total protein was determined using the CBQCA protein quantitation kit (Molecular Probes, Eugene, OR). Midway sections were mounted and stained with H\&E after methanol fixation.

Cell culture. Mycoplasma-free human prostate adenocarcinoma LNCaP (18) and 22Rv1 cells (19) were obtained from ATCC (Manassas, VA) and maintained in RPMI-1640 supplemented with 10\% FBS (Hyclone, Logan, UT), $1 \mathrm{mM}$ sodium pyruvate, $10 \mathrm{mM}$ Hepes and antibiotics $(100 \mathrm{U} / \mathrm{ml}$ penicillin sodium, $100 \mu \mathrm{g} / \mathrm{ml}$ streptomycin sulfate, $0.25 \mu \mathrm{g} / \mathrm{ml}$ amphotericin B). Media and supplements were obtained from Invitrogen (Burlington, ON, Canada). Prostate cancer cells were grown till $70-80 \%$ confluency and washed three times with PBS after which serum-free medium was added. After 5 days, the medium was collected and the cells were lysed using $50 \mathrm{mM}$ Tris-Cl, pH 8.0, $150 \mathrm{mM} \mathrm{NaCl}, 1 \% \mathrm{NP}-40$. The conditioned media (CM) were concentrated 12-20 times using Centricon centrifugal devices (Fisher Scientific, Ottawa, ON, Canada) with a cut-off of $10 \mathrm{kDa}$.

Western blot analysis and PSA ELISA. Cell numberstandardised CM, cell lysates and protein-standardised tumour homogenates were resolved in non-reducing 10\% SDS-PAGE. Prestained protein molecular weight standards were obtained from Invitrogen. Proteins were transferred onto a Hybond-C nitrocellulose membrane. The membrane was incubated with the primary antibody [anti-PSA, 1/400, Santa Cruz Biotechnology Inc. (Santa Cruz, CA) or anti-PSA-ACT, 1/500, Fitzgerald Industries Int. Inc. (Concord, MA)]. Secondary anti-mouse antibody conjugated with HRP (1/2000, Santa Cruz) was used in conjunction with chemiluminescence detection. The positive control, PSA isolated from seminal fluid, was obtained from Chemicon International (Temecula, CA).

The amount of PSA in serum, CM and tumour homogenates was quantified using a commercially available ELISA kit (Medicorp, Montreal PQ, Canada) against a standard curve (0.2-50 ng PSA $/ \mathrm{ml}$ ) provided with the kit. The amount of PSA is expressed as $\mathrm{ng} / \mu \mathrm{l}$ in the case of serum and CM or as $\mathrm{ng} / \mu \mathrm{g}$ of total protein for the homogenates.

Enzymatic activity assays. Enzymatic activity was determined using the synthetic chromogenic substrate S-2586 (DiaPharma, West Chester, $\mathrm{OH}$ ) or using fibronectin as a substrate. Hydrolysis of S-2586 upon incubation with the samples in $0.1 \mathrm{M}$ sodium phosphate buffer and $0.01 \%$ Tween-20 (pH 8.0) at $37^{\circ} \mathrm{C}$ was followed spectrophotometrically at $405 \mathrm{~nm}$. The rate of degradation was determined against a standard curve of $p$-nitroaniline $(1 \mu \mathrm{M}-0.4 \mathrm{mM})$ and expressed as nmol/h. The specific activity is calculated per ng of PSA per sample. Fibronectin degradation experiments were carried out by incubating tumour samples $(5 \mu \mathrm{g})$ in the presence of $2.5 \mu \mathrm{g}$ human fibronectin (Sigma-Aldrich, Oakville, ON, Canada or Chemicon) for 4 or $24 \mathrm{~h}$ at $37^{\circ} \mathrm{C}$, followed by separation on 5-20\% SDS-PAGE and staining with Coomassie Blue. Fibronectin enzymography was carried out by adding $0.4 \mathrm{mg} /$ $\mathrm{ml}$ fibronectin to the separating gel of a $12 \%$ SDS-PAGE. After protein separation, the gel was incubated for $30 \mathrm{~min}$ in $2.5 \%$ Triton $\mathrm{X}-100$ and subsequently in $30 \mathrm{mM}$ Tris-Cl $(\mathrm{pH} 7.5), 100 \mathrm{mM} \mathrm{NaCl}$ at $37^{\circ} \mathrm{C}$. After $72 \mathrm{~h}$, the gel was stained with Coomassie Blue.

\section{Results}

PSA expression in human prostate cancer cell lines. Human prostate adenocarcinoma $\mathrm{LNCaP}$ and 22Rv1 cell lines express PSA, albeit to differing degrees (20-22). We confirmed the expression of PSA in these cell lines by quantitative RT-PCR, Western blot analysis and ELISA. By RT-PCR, LNCaP cells expressed 96.4 times more PSA than 22Rv1 cells (data not shown). PSA secreted into the medium by the LNCaP and $22 \mathrm{Rv} 1$ cells amounted to $846.9 \pm 154.1$ and $21.6 \pm 0.56 \mathrm{ng} /$ day $/ 10^{5}$ cells, respectively, as determined using ELISA. By Western blotting, however, PSA could not be detected in the 22Rv1-CM. In LNCaP-CM the majority of the PSA was present in the 29-kDa form (Fig. 1B). Western blots probed with an antibody specific for PSA bound to $\alpha 1$-antichymotrypsin (PSA-ACT) demonstrated this form of PSA was absent in the LNCaP-CM (Fig. 1A).

PSA expression in human samples. Serum of six patients with histologically documented prostate adenocarcinoma and a level of serum PSA >100 ng/ml was collected. As determined by Western blot analysis only PSA-ACT (at $79 \mathrm{kDa}$ ), but not free PSA, was detectable in serum (Fig. 1A and B). Tumour specimens were also collected from nine prostate cancer patients with Gleason scores between 6 and 9. The Gleason score for each sample was obtained from the original patient records and independently assessed using one H\&E-stained midway section from each of the frozen samples. One of the nine samples, R238, was recorded as Gleason score 5, but this 


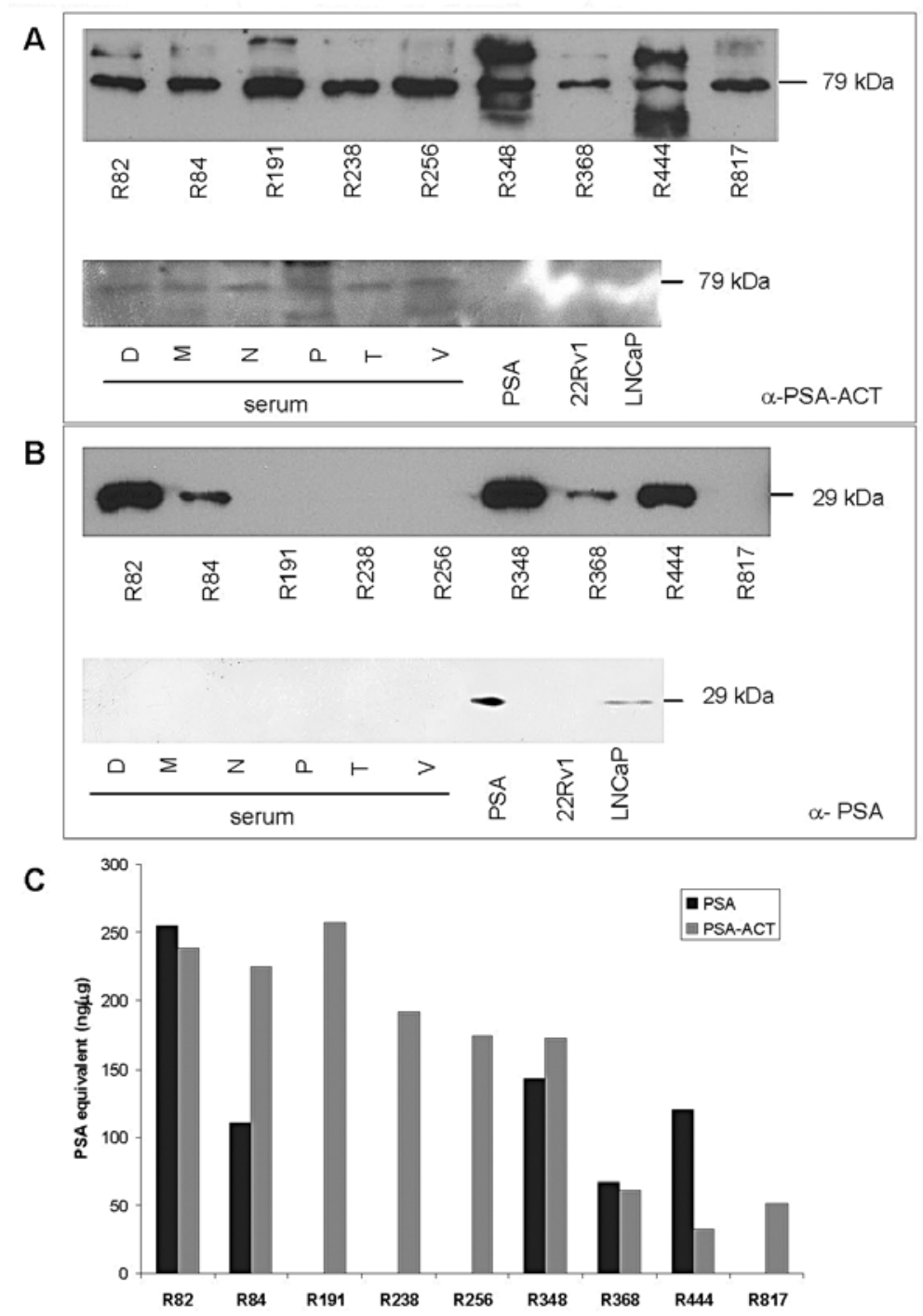

Figure 1. PSA expression determined by Western blot analysis. (A) Homogenised prostate tumour samples (5 $\mu \mathrm{g}$ per sample) were run under non-reducing conditions, transferred to nitrocellulose membrane and probed for (A) PSA bound to $\alpha 1$-antichymotrypsin (PSA-ACT), or for (B) PSA. Samples also included serum samples (D, M, N, P, T, and V), concentrated CM obtained from human prostate adenocarcinoma LNCaP or 22Rv1 cells cells (20 $\mu 1)$ and 25 ng PSA. For the sera an equivalent of $6 \mathrm{ng}$ PSA, as calculated from the results of the PSA-ELISA, was loaded per lane. (C) Densitometric analyses of the bands corresponding to PSA and PSA-ACT as observed in each of the nine tumour homogenates by Western blot analyses shown in (A) and (B).

could not be independently confirmed due to the insufficient quality of the frozen section. Frozen tumour specimens were homogenised and subjected to Western blot analysis and ELISA to detect PSA. All tumour homogenate samples contained PSA bound to ACT, to differing amounts (Fig. 1A). Free PSA was detected in five out of the nine prostate tumour samples (Fig. 1B). The same five PSA-positive homogenates as determined by Western blot analysis were also clearly positive for PSA by ELISA (Table I). The amount of PSA detected by ELISA ranged from 3.14 \pm 0.67 to $12.21 \pm 3.62$ $\mathrm{ng} / \mu \mathrm{g}$ protein. Densitometry of the bands corresponding to $29 \mathrm{kDa}$ PSA-form as determined by Western blotting (Fig. 1C) correlated very well with the results obtained by PSA ELISA results $\left(r^{2}=0.962, p=0.000\right)$.

Activity of PSA as measured by the cleavage of the synthetic substrate $S$-2586. To detect enzymatic PSA activity in the different samples, the synthetic chymotrypsin substrate S-2586 was used. Concentrated CM obtained from human prostate cancer LNCaP and 22 Rv1 cells showed little, but detectable PSA activity towards S-2586 (Table II). The activity amounted to $0.011 \mathrm{pmol} / \mathrm{h} / \mathrm{ng}$ PSA in the LNCaP cells and $0.29 \mathrm{pmol} /$ $\mathrm{h} / \mathrm{ng}$ PSA in the 22Rv1 cells. PSA activity was unaffected by the chymotrpysin inhibitor, Tosyl Phenylalanyl Chloromethyl Ketone (TPCK) (data not shown). Of the nine tumour homogenates, R256 showed very high activity against S-2586 (Table I), followed by R817. The activity of the tumour samples against S-2586 was inhibitable to a certain extent by TPCK. The highest inhibition of activity by $100 \mu \mathrm{g} / \mathrm{ml}$ TPCK amounted to 55\% in R256. In samples with low activity, such as R368 and R444, the inhibition was 34 and 19\%, respectively. In R191, the inhibition only amounted to $1.8 \%$. Serum samples showed comparable activity to five of the tumour samples with low activity. The most activity was found in serum $\mathrm{V}$, which contained the lowest amount of PSA $(0.20 \pm 0.03 \mathrm{ng} / \mu \mathrm{l})$. 
Table I. Enzymatic activity of PSA in human prostate tumour homogenates. ${ }^{a}$

\begin{tabular}{lcccc}
\hline Sample & Gleason Score & $\begin{array}{c}\text { Amount of PSA } \\
\text { (ng/ } \mu \text { g protein) }\end{array}$ & $\begin{array}{c}\text { PSA activity } \\
(\mathrm{nmol} / \mathrm{h} / \mu \text { g protein })\end{array}$ & $\begin{array}{c}\text { Specific activity } \\
(\mathrm{nmol} / \mathrm{h} / \mathrm{ng} \text { PSA) }\end{array}$ \\
\hline R82 & 6 & $12.21 \pm 3.62$ & $0.25 \pm 0.05$ & $0.02 \pm 0.01$ \\
R84 & 6 & $3.43 \pm 0.67$ & $0.29 \pm 0.05$ & $0.09 \pm 0.02$ \\
R191 & 8 & $0.04 \pm 0.02$ & $0.09 \pm 0.05$ & $2.31 \pm 1.35$ \\
R238 & $5^{\mathrm{b}}$ & $<0.04 \pm 0.02$ & $0.40 \pm 0.07$ & $>9.98 \pm 5.25$ \\
R256 & 9 & $<0.07 \pm 0.06$ & $3.10 \pm 0.35$ & $>44.27 \pm 38.27$ \\
R348 & 6 & $9.73 \pm 2.46$ & $0.76 \pm 0.13$ & $0.08 \pm 0.02$ \\
R368 & 7 & $3.14 \pm 0.67$ & $0.34 \pm 0.03$ & $0.11 \pm 0.03$ \\
R444 & 6 & $4.90 \pm 1.41$ & $0.48 \pm 0.08$ & $0.10 \pm 0.03$ \\
R817 & 9 & $<0.03 \pm 0.02$ & $0.78 \pm 0.13$ & $>26.09 \pm 17.84$ \\
\hline
\end{tabular}

aThe enzymatic activity of PSA ( \pm SEM) was determined in prostate tumour homogenates obtained from nine prostate cancer patients by the rate of cleavage of S-2586. The amount of PSA ( \pm SEM) was determined by ELISA. The activity is expressed per ng PSA or $\mu \mathrm{g}$ total protein. ${ }^{\mathrm{b}}$ Gleason score could not be independently confirmed.

Table II. Enzymatic activity of PSA in serum samples and LNCaP- and 22Rv1-conditioned medium. ${ }^{\mathrm{a}}$

\begin{tabular}{lcc}
\hline Sample & Amount of PSA $(\mathrm{ng} / \mu \mathrm{l})$ & Specific PSA activity $(\mathrm{nmol} / \mathrm{h} / \mathrm{ng}$ PSA) \\
\hline $\mathrm{D}$ & $2.10 \pm 0.18$ & $0.10 \pm 0.05$ \\
$\mathrm{M}$ & $1.06 \pm 0.09$ & $0.09 \pm 0.02$ \\
$\mathrm{~N}$ & $0.92 \pm 0.07$ & $0.12 \pm 0.05$ \\
$\mathrm{P}$ & $0.23 \pm 0.05$ & $0.16 \pm 0.08$ \\
$\mathrm{~T}$ & $3.77 \pm 0.17$ & $0.05 \pm 0.01$ \\
$\mathrm{~V}$ & $0.20 \pm 0.03$ & $0.70 \pm 0.12$ \\
& & $(\mathrm{pmol} / \mathrm{h} / \mathrm{ng}$ PSA) \\
LNCaP-CM & $3843.2 \pm 699.2$ & $0.011 \pm 0.001$ \\
22Rv1-CM & $72.63 \pm 1.87$ & $0.29 \pm 0.09$
\end{tabular}

aThe enzymatic activity of PSA $( \pm$ SEM) was determined in serum samples obtained from six prostate cancer patients and in concentrated medium conditioned for 5 days by human prostate adenocarcinoma LNCaP or 22Rv1 cells by the rate of cleavage of S-2586. The amount of PSA $( \pm$ SEM) was determined by ELISA. The enzymatic activity is expressed per ng PSA.

Activity of PSA as measured by the cleavage of fibronectin. Fibronectin is one of the physiological substrates of PSA (23). Enzymatic activity of PSA was measured against fibronectin in two different ways. Enzymography was carried out by adding $0.4 \mathrm{mg} / \mathrm{ml}$ fibronectin to the separating gel and subsequent incubation to allow degradation followed by Coomassie Blue staining. Activity towards fibronectin was observed at $29 \mathrm{kDa}$ in LNCaP CM (Fig. 2B). Fibronectin degrading activity was also observed in sera at molecular weights corresponding to 28 and $79 \mathrm{kDa}$. Fig. 2A shows the activity observed in the tumour homogenates. In the tumour samples R191, R238, and R444, activity was observed at molecular weights corresponding to 28 and $29 \mathrm{kDa}$, whereas R256 showed fibronectinolytic activity at a slightly higher molecular weight and at $>90 \mathrm{kDa}$. Tumour sample, R82, clearly showed three bands $\sim 30 \mathrm{kDa}$.

Fibronectin was also directly incubated with tumour homogenates at $37^{\circ} \mathrm{C}$ for 4 and $24 \mathrm{~h}$ and subsequently run on a gradient SDS-PAGE of 5-20\% (Fig. 3). Tumour sample, R256, clearly contained degradative capacity towards fibronectin, as all three higher molecular weight protein bands $\sim 170,140$ and $105 \mathrm{kDa}$ disappeared upon $4 \mathrm{~h}$ incubation. The same also happened in the presence of R82, but to a lesser extent. The degradation could be inhibited by the addition of $200 \mu \mathrm{M} \mathrm{Zn}^{2+}$. PSA (200 ng), however, was unable to degrade fibronectin over $4 \mathrm{~h}$, whereas $2.8 \mu \mathrm{g}$ PSA was sufficient, especially when the incubation time was increased to $24 \mathrm{~h}$. The degradation of fibronectin by R256 could be inhibited by TPCK, but again only partially.

\section{Discussion}

Western blot analysis shows that the majority of PSA was present in the 29-kDa form in LNCaP-CM, as previously reported (24). In the $22 \mathrm{Rv} 1$ cells, PSA expression was undetectable by Western blotting, but was confirmed by 
A

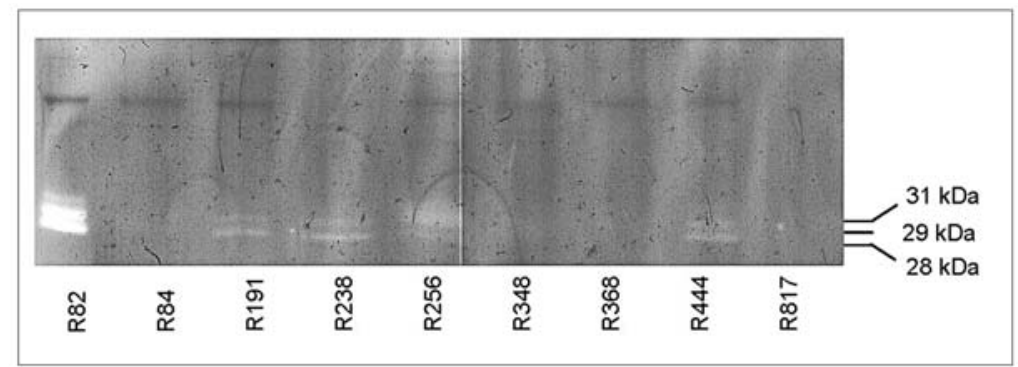

B

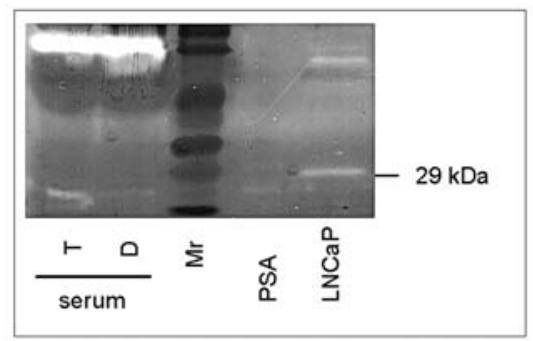

Figure 2. Detection of enzymatic activity as determined by fibronectin enzymography. (A) Fibronectin enzymography of tumour homogenates obtained from prostate adenocarcinoma (2.5 $\mu \mathrm{g}$ each). The activity of different forms of PSA towards fibronectin at $\mathrm{M}_{\mathrm{r}} 28$, 29, and $31 \mathrm{kDa}$ is indicated. (B) Fibronectin enzymography using concentrated $\mathrm{CM}$ of human prostate adenocarcinoma LNCaP cells and sera from two prostate cancer patients. For the sera an equivalent of $6 \mathrm{ng}$ PSA, as calculated from the results of the PSA-ELISA, was loaded per lane.

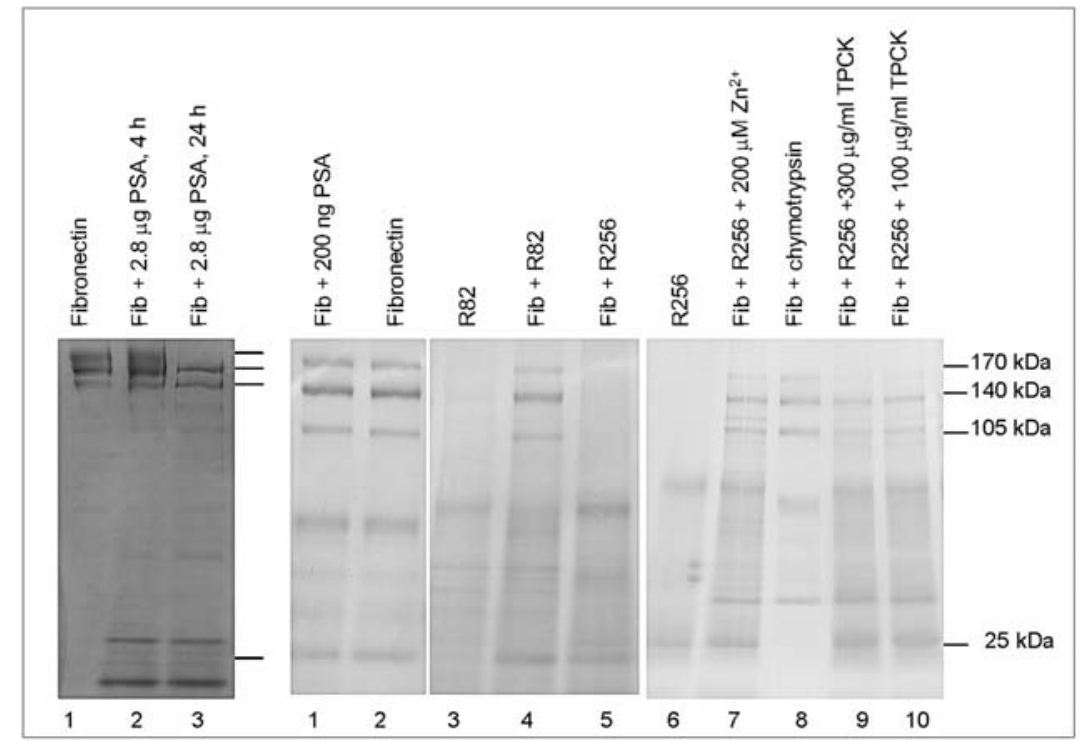

A

B

Figure 3. Fibronectin degradation. (A) Degradative activity of $2.8 \mu \mathrm{g}$ PSA incubated for 4 and $24 \mathrm{~h}$ (lanes 2 and 3, respectively) together with $5 \mu \mathrm{g}$ fibronectin (Chemicon) as a substrate. Samples were incubated at $37^{\circ} \mathrm{C}$ and run on a 5-20\% gradient SDS-PAGE. Lane 1 represents $5 \mu \mathrm{g}$ fibronectin alone incubated for 24 h. (B) Degradative activity determined in tumour homogenates R82 and R256 in the presence or absence of TPCK or Zn ${ }^{2+}$ using fibronectin (Sigma-Aldrich) as a substrate. R82 and R256 (2.5 $\mu \mathrm{g})$ alone are shown in lanes 3 and 6, respectively. Fibronectin alone is shown in lane 2. Fibronectin incubated with $200 \mathrm{ng}$ PSA, R82 or R256 in lanes 1, 4 and 5, respectively. TPCK at $100 \mu \mathrm{g} / \mathrm{ml}$ (lane 10) or $300 \mu \mathrm{g} / \mathrm{ml}$ (lane 9) or $200 \mu \mathrm{M} \mathrm{Zn}^{2+}$ (lane 7) were added to the incubation of R256 and fibronectin as inhibitors of chymotrypsin and PSA, respectively. Fibronectin incubated with chymotrypsin ( 3 ng) is shown in lane 8. Samples were incubated at $37^{\circ} \mathrm{C}$ for $4 \mathrm{~h}$ and run on a 5-20\% gradient SDS-PAGE. The fibronectin bands with calculated molecular weights of 170, 140, 105 and $25 \mathrm{kDa}$ are indicated.

ELISA. The two minor additional bands that were observed in LNCaP-CM when an increased amount of sample was loaded (not shown), most likely represent slightly different forms of PSA, such as N-terminally truncated forms of PSA $(21,25)$. In the LNCaP-conditioned media PSA-ACT was absent, even though these cells express ACT as by determined by RT-PCR (24). This suggests that PSA secreted by LNCaP cells is not in the active form, as ACT can only complex with activated PSA (26). In serum, the opposite was true; the predominant form in serum was PSA-ACT, free PSA was not detectable. This confirmed that PSA in serum is primarily bound to its inhibitors (26). PSA-ACT was also detectable in all nine tumour samples analysed, albeit to differing amounts. Free PSA was only detected in five out of the nine 
prostate tumour samples. The same five PSA-positive samples were also clearly positive for PSA by ELISA. Regression analysis showed that the densitometry of the bands corresponding to $29 \mathrm{kDa}$ PSA-form as determined by Western blotting (Fig. 1C) correlated very well to the results obtained by ELISA $\left(\mathrm{r}^{2}=0.962, \mathrm{p}=0.000\right)$. Interestingly, when densitometric data for free PSA and PSA-ACT were combined, the correlation was less statistically significant $\left(r^{2}=0.724, p=0.028\right)$, suggesting that the antibodies utilised by the ELISA do not have equal affinity for free PSA and PSA-ACT.

To measure the enzymatic activity of PSA in the various samples, several approaches were taken. Both S-2586, a synthetic chymotrypsin substrate and fibronectin were employed as substrates. S-2586 has been used extensively to measure PSA activity $(21,22,27)$. However, PSA cleaves its physiological substrates at many different sites and amino acids (15), therefore the use of fibronectin as a substrate may be more biologically relevant. The LNCaP-CM showed little, but detectable PSA activity towards fibronectin by enzymography and S-2586 (Figs. 2B and 3), respectively. Using enzymography, the LNCaP-CM showed activity towards fibronectin at 29 and $79 \mathrm{kDa}$, indicative of PSA and PSA-ACT. From these results, combined with our ELISA data, we conclude that the LNCaP cells produced more, but less active PSA when compared to the $22 \mathrm{Rv} 1$ cells. This confirms earlier reports that PSA produced by $\mathrm{LNCaP}$ cells is $\mathrm{N}$-terminally truncated or nicked $(21,22,24,25)$. Surprisingly, when compared to the prostate cancer cells, the serum samples showed much higher activity towards S-2586. The most active serum was serum V, which contained the lowest amount of PSA. Fibronectinolytic activity was observed at $28 \mathrm{kDa}$ in the sera, but the major activity was found at a molecular weight of $>79 \mathrm{kDa}$ consistent with the large amounts of PSA-ACT found by Western blot analysis.

Of the nine tumour homogenates, R256 showed very high activity using all three methods. R256 exhibited an activity of $44.3 \pm 38.3 \mathrm{nmol} / \mathrm{h} / \mathrm{ng}$ PSA towards S-2586. Activity of three of the nine tumour samples (R238, R256 and R817) against S-2586 was at least 10-fold higher than the other six. These higher activities were in part due to the low presence of PSA, but were still high when the activity was expressed per $\mu \mathrm{g}$ protein (Table I). Since PSA activity is unaffected by TPCK, a chymotrpysin inhibitor, we used it to evaluate the contribution of PSA in the tumour homogenates. The highest inhibition by $100 \mu \mathrm{g} / \mathrm{ml}$ TPCK amounted to $55 \%$ in R256. The activity of most other tumour samples was inhibited only to a certain extent by TPCK (1.8-34\%). By enzymography, activity towards fibronectin was observed in five tumour homogenates (R82, R238, R191, R256 and R444). In tumour samples R191, R238 and R444, activity was observed at molecular weights of 28 and $29 \mathrm{kDa}$, likely corresponding to PSA and pro-PSA. Tumour sample R82 clearly showed three bands, $\sim 30 \mathrm{kDa}$, with molecular weights corresponding to preproPSA, pro-PSA and PSA. By Western blot analysis, we also observed these three bands when increasing amount of sample was loaded (data not shown).

Tumour homogenates were also directly incubated with fibronectin at $37^{\circ} \mathrm{C}$ for 4 and $24 \mathrm{~h}$ and the degradation was determined. Again, tumour sample R256 clearly was able to degrade fibronectin, as all three higher molecular weight protein bands $\sim 170,140$ and $105 \mathrm{kDa}$ disappeared upon $4 \mathrm{~h}$ incubation. The degradation of fibronectin by R256 could only be partially inhibited by TPCK. Fibronectin incubated with chymotrpysin, however, remained largely intact. This suggests that a chymotrpysin-like TPCK-inhibitable enzyme may have been partly responsible for the degradative activity found in R256.

The different assays to determine PSA activity demonstrated somewhat inconsistent results. When fibronectin was incubated with tumour homogenates, it is clear that both R82 and R256 contained degradative capacity towards fibronectin. The degradation could be inhibited by $200 \mu \mathrm{M} \mathrm{Zn}{ }^{2+}$, indicating that PSA, or another related kallikrein, may be responsible for the degradation, at least in part $(6,15)$. However, R256 only contained PSA-ACT and no detectable PSA, neither by ELISA nor Western blot analysis. Using the same method, we also showed that $200 \mathrm{ng}$ PSA was not sufficient to degrade fibronectin over $4 \mathrm{~h}$ (Fig. 3B, lane 1). Other proteases can also degrade fibronectin, most importantly the matrix metalloproteinases MMP-2, -7 and -9 (28). Matrilysin (MMP-7) would be a likely candidate with a molecular weight of $29.7 \mathrm{kDa}$ in its latent form. However, $\mathrm{Zn}^{2+}$ does not inhibit MMP-7. The gelatinases MMP-2 and -9 have a higher molecular weight, of 72 and $92 \mathrm{kDa}$, respectively. Additional likely candidates are other prostatically expressed kallikreinrelated peptidases, such as KLK2 and KLK4, that have many similarities with PSA, including overlapping substrate specificities and similar apparent molecular weights of 34 (29) and $40 \mathrm{kDa}(30)$, respectively. Moreover, fibronectin is hydrolysed more efficiently by KLK2 than by PSA (31). On the other hand, S-2586 is not a substrate for KLK2 and R256 showed high activity towards S-2586. Tumour sample R82, however, did not show appreciable activity using S-2586 as a substrate, but exhibited clear PSA expression by Western blot analysis, ELISA and by fibronectin enzymography. The same holds true for R444, but to a lesser extent. Taken together, these data provide evidence for the fact that free PSA appears to exist in diverse forms of very different specific activity. The nature of the proteolytic band at $\sim 30 \mathrm{kDa}$ in R256 remains unclear and will be determined in future investigations.

The prevalent form of PSA in prostate tumour samples, according to molecular weight, appeared to be the $79 \mathrm{kDa}$ PSA-ACT form; other forms of PSA, most likely corresponding to free PSA, were also detectable in five of the nine samples. The tumour homogenates from the patients with the higher Gleason scores of 8 and 9 had no detectable PSA, consistent with reports showing that PSA correlates inversely with tumour stage and cytological grade $(12,13)$. The enzymatic activity of PSA in prostate cancer tissue has not been previously studied, with the exception of a report by Denmeade et al (14) using explant tissue from human prostate tumour samples to conclude that $>80 \%$ of PSA is active. The activity was measured using a fluorescent synthetic oligopeptide, which may not be biologically relevant, and did not take into account the fact that PSA may exist in different forms of different specific activity. In conclusion, our results from the human prostate cancer tissue samples and two human prostate cancer cell lines showed that free PSA appears to exist in diverse forms of very different specific activity. This may 
have implications for the invasive capacity of human prostate cancer, as evidence suggests that the enzymatic activity of PSA may be involved in these processes.

\section{Acknowledgements}

The authors are indebted to the patients for donating samples and thank Marisa Kubinec and Taylor Bureyko for technical assistance. Financial support was provided by the Canadian Institutes of Health Research (MOP 67201) and the Prostate Cancer Research Foundation of Canada.

\section{References}

1. Ries LAG, Eisner MP, Kosary CL, et al: SEER Cancer Statistics Review, 1975-2002. National Cancer Institute, Bethesda, MD, 2004

2. Jonsson M, Linse S, Frohm B, Lundwall A and Malm J: Semenogelins I and II bind zinc and regulate the activity of prostate-specific antigen. Biochem J 387: 447-453, 2005.

3. Lilja H: A kallikrein-like serine protease in prostatic fluid cleaves the predominant seminal vesicle protein. J Clin Invest 76: 1899-1903, 1985.

4. Réhault S, Monget P, Mazerbourg S, et al: Insulin-like growth factor binding proteins (IGFBPs) as potential physiological substrates for human kallikreins hK2 and hK3. Eur J Biochem 268: 2960-2968, 2001 .

5. Webber MM, Waghray A and Bello D: Prostate-specific antigen, a serine protease, facilitates human prostate cancer cell invasion. Clin Cancer Res 1: 1089-1094, 1995.

6. Ishii K, Otsuka T, Iguchi K, et al: Evidence that the prostatespecific antigen (PSA)/ $\mathrm{Zn}(2+)$ axis may play a role in human prostate cancer cell invasion. Cancer Lett 207: 79-87, 2004.

7. Weir EG, Partin AW and Epstein JI: Correlation of serum prostate specific antigen and quantitative immunohistochemistry. J Urol 163: 1739-1742, 2000.

8. McCormack RT, Rittenhouse HG, Finlay JA, et al: Molecular forms of prostate-specific antigen and the human kallikrein gene family: a new era. Urology 45: 729-744, 1995.

9. Pampalakis G and Sotiropoulou G: Tissue kallikrein proteolytic cascade pathways in normal physiology and cancer. Biochim Biophys Acta 1776: 22-31, 2007.

10. Magklara A, Scorilas A, Stephan C, et al: Decreased concentrations of prostate-specific antigen and human glandular kallikrein 2 in malignant versus nonmalignant prostatic tissue. Urology 56: 527-532, 2000.

11. Qiu SD, Young CY, Bilhartz DL, et al: In situ hybridization of prostate-specific antigen mRNA in human prostate. J Urol 144: 1550-1556, 1990.

12. Stege RH, Tribukait B, Carlstrom KA, Grande M and Pousette AH: Tissue PSA from fine-needle biopsies of prostatic carcinoma as related to serum PSA, clinical stage, cytological grade, and DNA ploidy. Prostate 38: 183-188, 1999.

13. Stege R, Grande M, Carlstrom K, Tribukait B and Pousette A: Prognostic significance of tissue prostate-specific antigen in endocrine-treated prostate carcinomas. Clin Cancer Res 6: 160-165, 2000.

14. Denmeade SR, Sokoll LJ, Chan DW, Khan SR and Isaacs JT: Concentration of enzymatically active prostate-specific antigen (PSA) in the extracellular fluid of primary human prostate cancers and human prostate cancer xenograft models. Prostate 48: 1-6, 2001 .
15. Malm J, Hellman J, Hogg P and Lilja H: Enzymatic action of prostate-specific antigen (PSA or hK3): substrate specificity and regulation by $\mathrm{Zn}(2+)$, a tight-binding inhibitor. Prostate 45 : 132-139, 2000.

16. Gleason DF: Histologic grading of prostate carcinoma: a perspective. Hum Pathol 23: 273-279, 1992.

17. Humphrey PA: Gleason grading and prognostic factors in carcinoma of the prostate. Mod Pathol 17: 292-306, 2004.

18. Horoszewicz JS, Leong SS, Kawinski E, et al: LNCaP model of human prostatic carcinoma. Cancer Res 43: 1809-1818, 1983.

19. Sramkoski RM, Pretlow TG II, Giaconia JM, et al: A new human prostate carcinoma cell line, 22Rv1. In Vitro Cell Dev Biol Anim 35: 403-409, 1999.

20. Attardi BJ, Burgenson J, Hild SA and Reel JR: Steroid hormonal regulation of growth, prostate specific antigen secretion, and transcription mediated by the mutated androgen receptor in CWR22Rv1 human prostate carcinoma cells. Mol Cell Endocrinol 222: 121-132, 2004.

21. Herrala A, Kurkela R, Vihinen M, Kalkkinen N and Vihko P: Androgen-sensitive human prostate cancer cells, LNCaP, produce both N-terminally mature and truncated prostate-specific antigen isoforms. Eur J Biochem 255: 329-335, 1998.

22. Kumar A, Mikolajczyk SD, Hill TM, Millar LS and Saedi MS: Different proportions of various prostate-specific antigen (PSA) and human kallikrein 2 (hK2) forms are present in noninduced and androgen-induced LNCaP cells. Prostate 44: 248-254, 2000 .

23. Webber MM and Waghray A: Urokinase-mediated extracellular matrix degradation by human prostatic carcinoma cells and its inhibition by retinoic acid. Clin Cancer Res 1: 755-761, 1995.

24. Corey E, Brown LG, Corey MJ, Buhler KR and Vessella RL: LNCaP produces both putative zymogen and inactive, free form of prostate-specific antigen. Prostate 35: 135-143, 1998.

25. Väisänen V, Lövgren J, Hellman J, Piironen T, Lilja H and Pettersson K: Characterization and processing of prostate specific antigen (hK3) and human glandular kallikrein (hK2) secreted by LNCaP cells. Prostate Cancer Prostatic Dis 2: 91-97, 1999.

26. Kumar A, Mikolajczyk SD, Goel AS, Millar LS and Saedi MS: Expression of prostate-specific antigen by mammalian cells and its conversion to mature, active form by kallikrein 2. Cancer Res 57: 3111-3114, 1997.

27. Takayama TK, Fujikawa K and Davie EW: Characterization of the precursor of prostate-specific antigen. Activation by trypsin and by human glandular kallikrein. J Biol Chem 272: 21582-21588, 1997.

28. Malemud CJ: Matrix metalloproteinases (MMPs) in health and disease: an overview. Front Biosci 11: 1696-1701, 2006.

29. Saedi MS, Hill TM, Kuus-Reichel K, et al: The precursor form of the human kallikrein 2, a kallikrein homologous to prostatespecific antigen, is present in human sera and is increased in prostate cancer and benign prostatic hyperplasia. Clin Chem 44: 2115-2119, 1998.

30. Dong Y, Kaushal A, Bui L, et al: Human kallikrein 4 (KLK4) is highly expressed in serous ovarian carcinomas. Clin Cancer Res 7: 2363-2371, 2001 .

31. Deperthes D, Frenette G, Brillard-Bourdet M, et al: Potential involvement of kallikrein $\mathrm{hK} 2$ in the hydrolysis of the human seminal vesicle proteins after ejaculation. J Androl 17: 659-665, 1996. 